\title{
Heel of the Foot
}

National Cancer Institute

\section{Source}

National Cancer Institute. Heel of the Foot. NCI Thesaurus. Code C161381.

The rounded back part of the foot below the ankle and behind the arch. 